\title{
New Benzimidazole Substituted Cobalt and Manganese Phthalocyanines as Hydrogen Peroxide Catalysts for Laundry Bleaching
}

\author{
Pinar Sen, ${ }^{\mathrm{a}, \mathrm{b} @}$ S. Zeki Yildiz, ${ }^{\mathrm{b}}$ Sibel Demir Kanmazalp, ${ }^{\mathrm{c}, \mathrm{d}}$ and Necmi Dege ${ }^{\mathrm{e}}$ \\ ${ }^{a}$ Uskudar University, Faculty of Engineering and Natural Sciences, Department of Forensic Science, 34662 Istanbul, Turkey \\ 'Sakarya University, Faculty of Arts and Sciences, Department of Chemistry, 54187 Sakarya, Turkey \\ 'Technical Sciences, Gaziantep University, Gaziantep, Turkey \\ dPhysics Department, Gebze Technical University, Kocaeli, Turkey \\ 'Ondokuz Mayls University, Faculty of Arts and Sciences, Department of Physics, 55139 Samsun, Turkey \\ ${ }^{\circledR}$ Corresponding authorE-mail: pinar.sen@uskudar.edu.tr
}

\begin{abstract}
The context of this study is based on the synthesis of 4-(4-(1H-benz[d]imidazol-2-yl)phenoxy group substituted phthalonitrile (2), 4-(4-(1-allyl-1H-benz[d]imidazol-2-yl)phenoxy group substituted phthalonitrile (3) that were reported for the first time. These phthalonitrile derivatives were also converted to the corresponding cobalt(II) and manganese(III) phthalocyanines (4-7) with four nitrogen-containing groups which helped to stabilize the redox active metal during the oxidation process. All novel compounds synthesized in this study were fully characterized by general spectroscopic techniques such as FT-IR, UV-Vis, ${ }^{1} \mathrm{H} N M R,{ }^{13} \mathrm{C} N \mathrm{NR}$ spectroscopy and mass spectrometry. The compounds 2-(4-hydroxyphenyl)benzimidazole (1) and 4-(4-(1-allyl-1H-benz[d]imidazol-2-yl)phenoxy group substituted phthalonitrile (3) were obtained as single crystal and exact structure of these compounds has also been determined using X-ray diffraction technique at 296 K. Bleach catalyst activity of the prepared phthalocyanine complexes (4-7) was examined by degradation of morin. The catalysts had better activity for color removing in solutions at ambient temperature than to that of tetraacetylethylenediamine (TAED).
\end{abstract}

Keywords: Benzimidazole, bleach catalyst, hydrogen peroxide, metallo phtalocyanines, synthesis, X-Ray structure determination.

\section{Новые бензимидазолзамещенные фталоцианинаты кобальта и марганца как катализаторы пероксидного отбеливания}

\author{
П. Сен, ${ }^{\text {a,b@ }}$ С. З. Йилдиз, ${ }^{\text {b }}$ C. А. Канмазалп, ${ }^{\text {c,d }}$ Н. Аеге
}

а Университет Ускюдар, факультет инженерии и естественных наук, кафедра судебной медицинь, 34662 Стамбул, Туричия

${ }^{\mathrm{b}}$ Сакарский университет, факультет искусств и наук, кафедра химии, 54187 Сакарья, Туриия

'Газиантепский университет, Газиантеп, Туричия

'Кафедра физики, Технический университет Гебзе, Коджаэли, Туричия

е Университет Ондокуз Майис, факультет искусств и наук, кафедра физики, 55139 Самсун, Туричя

${ }^{\circledR}$ E-mail: pinar.sen@uskudar.edu.tr

\begin{abstract}
Впервые были получены 4-(4-(1Н-бензо[d]имидазол-2-ил)фенокси- (2) и 4-(4-(1-аллил-1Н-бензо[d]имидазол-2-ил) фенокси- (3) замещенные фталонитрильл. На их основе были синтезированы комплексы соответствующих фталоциианинов с кобальтом(II) и марганцем(III) (4-7) с четырьмя азотсодержащзими группами, повымающзими устойчивость редокс-активного металла к окислению. Полученные соединения были охарактеризованы с помощью спектральных методов (ИК, ЭСП, ${ }^{1} \mathrm{H}{ }^{13} \mathrm{C} \mathrm{ЯМР)} \mathrm{и} \mathrm{масс-спектрометрии.} \mathrm{Для} \mathrm{2-(4-гидроксифенил)}$
\end{abstract}


бензимидазола (1) и 4-(4-(1-аллил-1Н-бензо[d]имидазол-2-ил)феноксизамещееного фтталонитрила (3) удалось получить монокристалль и определить их структуру методом рентгеноструктурного анализа при 296 К. Реакция разложения морина использовалась для оченки каталитических свойств комплексов 4-7 в процессе отбеливания. Изученные соединения проявили себя как более эффективные катализаторы отбеливания по сравнению с тетраацетилэтилендиамином (TAED).

Ключевые слова: Бензимидазол, катализатор отбеливания, пероксид водорода, металлофталоцианин, синтез, рентгеноструктурный анализ.

\section{Introduction}

Phthalocyanines (Pcs) and metallophthalocyanines (MPcs) have drawn considerable attention as molecular materials. The increasing interest in phthalocyanines arises from their thermal and chemical stability. Moreover, the architectural flexibility that allows the chemical and physical properties of these molecules to be regulated is an extraordinary feature for material science. ${ }^{[1]}$ MPc's have important uses not only as commercial pigments but also as important functional materials in many fields such as photodynamic cancer therapy (PDT), nonlinear optics, as electrical conductors, in high-density information storage disks and chemical sensors. ${ }^{[2]}$

In recent years, there has been a continuous interest in the search for new functional molecular materials for catalytic applications. Metallo-Pcs which contain redox active metals having wide range of oxidation states are preferred as the oxidation catalysts. ${ }^{[3]}$ The exceptional catalytic properties of phthalocyanines, such as oxidation of olefins, alkanes, alcohols and aromatic compounds have received considerable attention. ${ }^{[4-6]}$ Especially, cobalt and manganese phthalocyanines have been employed in oxidation reactions because of their high catalytic activities. ${ }^{[7,8]}$

Change of the central atom, its axial coordination or altering of peripheral substituents affect the efficiency of catalytic system. Among the substituted phthalocyanines, the heterocyclic groups containing nitrogen atom such as imidazole, benzimidazole derivatives have been received considerable attention. ${ }^{[9-10]}$ According to the literature manganese and cobalt phthalocyanines exhibit a special affinity to nitrogen-containing groups what stabilizes the redox active metal based active oxidative intermediate. ${ }^{[11]}$

Therefore, in present work, we chose benzimidazole moieties as substituent on new phthalocyanine derivatives. We reported the design, synthesis and characterization of four new phthalocyanine derivatives as the new bleach catalyst. We aimed to develop laundry bleaching at lower temperatures by means of decreasing activation energies with this kind of catalyst.

We investigated the bleaching performance of the prepared catalysts which defined as $4-(1 H$-benz $[d]$ imidazol2-yl)phenoxy substituted cobalt and manganese phthalocyanines and 4-(1-allyl-1H-benz[ $d]$ imidazol-2-yl)phenoxy substituted cobalt and manganese phthalocyanines at room temperature in the presence of combination of morin as hydrophilic dye and $\mathrm{H}_{2} \mathrm{O}_{2}$ as oxidant by online spectrophotometric method. ${ }^{[12]}$

We observed that the change of the metal on the phthalocyanines led to different catalytic activity on morin oxi- dation. When compared to the tetraacetylethylenediamine (TAED) used as commercial activator in existing detergents, we obtained more effective bleaching performance in a short time by applying the newly prepared bleach catalysts.

\section{Experimental}

\section{Chemicals and instruments}

The following chemicals were obtained from Sigma-Aldrich; $o$-Phenylenediamine, 4-hydroxybenzaldehyde, allyl bromide, acetonitrile, hexane, ethylacetate, dimethylformamide (DMF), chloroform $\left(\mathrm{CHCl}_{3}\right), n$-pentanol, methanol $(\mathrm{MeOH})$, ethanol (EtOH), diethylether, 1,8-diazabicyclo[5.4.0]undec-7-ene (DBU), $\mathrm{CoCl}_{2} \cdot 6 \mathrm{H}_{2} \mathrm{O}, \mathrm{K}_{2} \mathrm{CO}_{3}$, anhydrous $\mathrm{ZnCl}_{2}$. All other reagents and solvents were reagent grade quality and obtained from commercial suppliers. Hydrogen peroxide was used as industrial grade (50\%). All solvents were stored over molecular sieves $(4 \AA)$ after they dried and purified as described by Perrin and Armarego. ${ }^{[13]}$ Oxygen free inert atmosphere was supplied by argon through dualbank vacuum-gas manifold system. Deionized water was generated from MILLIPORE ultra-pure water supply system. ThinLayer chromatography (TLC) was performed using silica gel $60-\mathrm{HF} 254$ as an adsorbent. Column chromatography was performed with silica gel (Merck grade 60) and the size exclusion chromatography with Bio-beads gel (SX-1). Melting points (m.p.) were determined using a Barnstad-Electrotermel 9200 apparatus and uncorrected. Electronic spectra were recorded on a Shimadzu UV-2600 Pc-spectrophotometer with quartz cell of $1 \mathrm{~cm}$. Infrared spectra were recorded on a Perkin Elmer Spectrum two FT-IR spectrophotometer equipped with Perkin Elmer UATR-TWO diamond ATR and corrected by applying the atr-correction function of Perkin Elmer Spectrum software. ${ }^{1} \mathrm{H}$ and ${ }^{13} \mathrm{C}$ NMR spectra were recorded a Varian Mercury Plus $300 \mathrm{MHz}$ spectrometer. For MALDI-TOF spectra, the experiments were carried out using a Bruker microTOF (Germany) in Gebze Institute of Technology.

2-(4-Hydroxyphenyl)benzimidazole (1) The preparation of $\mathbf{1}$ was carried out by reaction of $o$-phenylenediamine and 4-hydroxybenzaldehyde according to the published literature. ${ }^{[14]}$ The obtained spectroscopic data are in accordance with the literature.

4-(4-(1H-benz [d]imidazol-2-yl)phenoxy)phthalonitrile (2) 2-(4-Hydroxyphenyl)benzimidazole (1) (1.2 g, $5.71 \mathrm{mmol})$ and 4-nitrophthalonitrile $(0.989 \mathrm{~g}, 5.71 \mathrm{mmol})$ were dissolved in DMF $(15 \mathrm{~mL})$ and degassed by argon in a dual-bank vacuumgas manifold system. After stirring for $15 \mathrm{~min}$, finely ground anhydrous $\mathrm{K}_{2} \mathrm{CO}_{3}(0.790 \mathrm{~g}, 5.71 \mathrm{mmol})$ was added portion-wise in $2 \mathrm{~h}$ with the efficient stirring. The suspension solution was maintained at $60{ }^{\circ} \mathrm{C}$ for $24 \mathrm{~h}$. The progress of the reaction was monitored by TLC using $\mathrm{CHCl}_{3}$-EtOAc (10:1) solvent system. When the reaction was completed, the crude product was precipitated by pouring into ice water. The occurred precipitate was collected by filtration, washed with hot water, ethanol, diethylether and dried in vacuo. The desired pure compound $\mathbf{1}$ was obtained in sufficient purity. Yield: $96 \%$ (1.84 g). M.p. $148{ }^{\circ} \mathrm{C}$. MS (MALDI-TOF): $\mathrm{m} / \mathrm{z}$ 
$336.081[\mathrm{M}]^{+}$. FT-IR (UATR-TWO TM $) v_{\text {max }} \mathrm{cm}^{-1}: 3576(\mathrm{NH}), 3102$ 2551 (C-H (Ar) and intermolecular H-bonding), $2232(-\mathrm{C} \equiv \mathrm{N}), 1657$ $(\mathrm{C}=\mathrm{N}), 1591-1559(\mathrm{C}=\mathrm{C}), 1496-1373(\mathrm{C}-\mathrm{C}), 1278$ (tert, $\mathrm{C}-\mathrm{N})$, 1246 (asym., Ar-O-Ar), 1212 (C-N), 1178 (sym., Ar-O-Ar), 737. UV-Vis (DMSO, $\left.1 \cdot 10^{-5} \mathrm{M}\right) \lambda_{\max }(\log \varepsilon) \mathrm{nm}: 254$ (4.49), 311 (4.44). ${ }^{1} \mathrm{H}$ NMR (DMSO- $\left.d_{6}\right) \delta_{\mathrm{H}}$ ppm: $8.26(\mathrm{~d}, 1 \mathrm{H}), 8.13(\mathrm{~d}, 1 \mathrm{H}), 7.91(\mathrm{~d}$, $2 \mathrm{H}), 7.59(\mathrm{~m}, 2 \mathrm{H}), 7.51(\mathrm{~d}, 1 \mathrm{H}), 7.35(\mathrm{~d}, 2 \mathrm{H}), 7.20(\mathrm{~d}, 2 \mathrm{H}), 5.74(\mathrm{~s}$, 1H). ${ }^{13} \mathrm{C}$ NMR (DMSO- $d_{6}$ ) $\delta_{\mathrm{C}}$ ppm: $161.10,155.95,151.08,140.64$, $137.06,129.41,128.07,124.01,123.47,122.89,121.22$, 117.47, $116.60,109.98,109.42$.

4-(4-(1-Allyl-1H-benz[d]imidazol-2-yl)phenoxy)phthalonitrile (3) 4-(4-(1H-benz[d]imidazol-2-yl)phenoxy)phthalonitrile (2) $(1.1 \mathrm{~g}, 3.27 \mathrm{mmol})$ and $\mathrm{K}_{2} \mathrm{CO}_{3}(0.860 \mathrm{~g}, 6.2 \mathrm{mmol})$ were dissolved in DMF $(15 \mathrm{~mL})$ and degassed by argon in a dual-bank vacuumgas manifold system. After stirring for 1 hour at room temperature, allyl bromide $(0.340 \mathrm{~mL}, 3.9 \mathrm{mmol})$ was added to the reaction medium. The suspension solution was maintained at $70{ }^{\circ} \mathrm{C}$ for $24 \mathrm{~h}$ under argon. The progress of the reaction was monitored by TLC using $\mathrm{CHCl}_{3}-\mathrm{MeOH}$ (10:1) solvent system. When the reaction was completed, the crude product was precipitated by pouring into ice water. The occurred precipitate was collected by filtration, washed with hot water and ethanol to dissolve any unwanted organic impurity. Further purification of the crude product was performed by column chromatography on silica-gel eluting with $\mathrm{CHCl}_{3}-\mathrm{MeOH}(10: 1)$ solvent system to give 3. Yield: $95 \%$ (1.17 g). M.p. $118{ }^{\circ} \mathrm{C}$. MS (MALDI-TOF): $m / z 375.853[\mathrm{M}+\mathrm{H}]^{+}$. FT-IR (UATR-TWO ${ }^{\text {TM }}$ ) $v_{\max } \mathrm{cm}^{-1}$ : 3069-3022 (Ar-C-H), 29852855 (aliph., C-H), $2231(\mathrm{C} \equiv \mathrm{N}), 1644(\mathrm{C}=\mathrm{N}), 1591-1526(\mathrm{C}=\mathrm{C})$, 1475-1384 (C-C), 1278 (tert, C-N), 1245 (asym., Ar-O-Ar), 1209 (C-N), 1164 (sym., Ar-O-Ar), 742. UV-Vis (DMSO, $\left.1 \cdot 10^{-5} \mathrm{M}\right) \lambda_{\mathrm{m}}$ (loge) nm: 256 (4.42), 295 (4.3). ${ }^{1} \mathrm{H}$ NMR (DMSO- $\left.d_{6}\right) \delta_{\mathrm{H}}$ ppm: 8.13 $(\mathrm{d}, 1 \mathrm{H}), 7.92(\mathrm{~d}, 1 \mathrm{H}), 7.86(\mathrm{~d}, 2 \mathrm{H}), 7.71-7.67(\mathrm{~m}, 1 \mathrm{H}), 7.52(\mathrm{~d}, 2 \mathrm{H})$, $7.36(\mathrm{~d}, 2 \mathrm{H}), 7.25(\mathrm{~d}, 2 \mathrm{H}), 6.16-6.03(\mathrm{~m}, 1 \mathrm{H}), 5.21(\mathrm{~d}, 1 \mathrm{H}), 4.95(\mathrm{~d}$, $2 \mathrm{H}), 4.88(\mathrm{~d}, 1 \mathrm{H}) .{ }^{13} \mathrm{C}$ NMR (DMSO- $\left.d_{6}\right) \delta_{\mathrm{C}} \mathrm{ppm}: 161.31,155.24$, $152.64,137.16,136.21,135.82,132.45,131.83,128.35,123.51$, $123.08,122.23,122.14,121.02,120.18,117.99,117.86,115.105$, $110.72,109.68,47.44$.

General procedures for the preparation of cobalt phthalocyanine derivatives $(4,6) 4-(4-(1 H$-benz $[d]$ imidazol-2-yl)phenoxy) phthalonitrile (2) $(0.1 \mathrm{~g}, 0.297 \mathrm{mmol})$ and 4-(4-(1-allyl-1H-benz [ $d]$ imidazol-2-yl)phenoxy)phthalonitrile (3) $(0.1 \mathrm{~g}, 0.266 \mathrm{mmol})$, $\mathrm{Co}(\mathrm{OAc})_{2}$ (0.026 g, $\left.0.149 \mathrm{mmol}\right)$ for 4, $\mathrm{Co}(\mathrm{OAc})_{2}$ (0.014 g, $0.0996 \mathrm{mmol})$ for $\mathbf{6}$ and $n$-pentanol $(2 \mathrm{~mL})$ were placed in a standard Schlenk tube in the presence of DBU (3 drops). The reaction mixture was purged by argon at room temperature and heated up to $140{ }^{\circ} \mathrm{C}$ for $12 \mathrm{~h}$. After cooling to the room temperature, the reaction mixture was precipitated by adding water-methanol $(1: 1)$. The precipitate was collected by centrifugation, washed several times with ethanol and water to dissolve any unwanted organic impurity and any unreacted metal salt and dried. Further purification of the phthalocyanine was performed by size exclusion chromatography on Biobeads gel (SX-1). The crude product was put onto the column and eluted with $\mathrm{CHCl}_{3}$, and the collected phases were concentrated on a rotary evaporator and re-precipitated with methanol. The desired pure CoPcs $\mathbf{4}$ and $\mathbf{6}$ were obtained as green solid.

Tetrakis[4-(4-(1H-benz[d]imidazol-2-yl)phenoxy)phthalocyaninatocobalt(II) (4) Yield: $42 \%$ (0.044 g). M.p. $>250{ }^{\circ} \mathrm{C}$. MS (MALDI-TOF): $m / z 1404.549$ [M] ${ }^{+}$. FT-IR (UATR-TWO ${ }^{\mathrm{TM}}$ ) $v_{\max }$ $\mathrm{cm}^{-1}: 3396(\mathrm{NH}), 3190-2593(\mathrm{C}-\mathrm{H}(\mathrm{Ar})$ and intermolecular H bonding), 1603-1503 (C=N, C=C), 1492-1371 (C-C), 1263 (tert, C-N), 1230 (asym., Ar-O-Ar), 1166 (C-N), 1049 (sym., Ar-O-Ar), 741. UV-Vis (DMAc, $1 \cdot 10^{-5}$ M) $\lambda_{\text {max }}(\log \varepsilon) \mathrm{nm}: 311$ (5.01), 604 (4.07), 666 (4.57).

Tetrakis [4-(4-(1-allyl-1H-benz[d]imidazol-2-yl)phenoxy) phthalocyaninatocobalt(II) (6) Yield: $52 \%\left(0.054\right.$ g). M.p. $>250{ }^{\circ} \mathrm{C}$. MS (MALDI-TOF): $m / z 1564.099$ [M] $^{+}$. FT-IR (UATR-TWO ${ }^{\mathrm{TM}}$ ) $v_{\max } \mathrm{cm}^{-1}: 3054$ (Ar., C-H), 2924-2855 (aliph., C-H), $1640(\mathrm{C}=\mathrm{N})$, 1602-1521 (C=C), 1469-1382 (C-C), 1280 (tert., C-N), 1230 (asym., Ar-O-Ar), 1162 (C-N), 1092 (sym., Ar-O-Ar), 740. UV-Vis (DMAc, $\left.1 \cdot 10^{-5} \mathrm{M}\right) \lambda_{\max }(\log \varepsilon) \mathrm{nm}: 299$ (5.07), 603 (4.39), 667 (4.97). General procedures for the preparation of manganese phthalocyanine derivatives $(5,7)$ 4-(4-(1H-benz $[d]$ imidazol-2-yl) phenoxy)phthalonitrile (2) $(0.1 \mathrm{~g}, 0.297 \mathrm{mmol})$ and 4-(4-(1-allyl$1 H$-benz $[d]$ imidazol-2-yl)phenoxy)phthalonitrile (3) (0.1 g, $0.266 \mathrm{mmol})$, anhydrous $\mathrm{MnCl}_{2}(0.019 \mathrm{~g}, 0.149 \mathrm{mmol})$ for $\mathbf{5}$, anhydrous $\mathrm{MnCl}_{2}(0.013 \mathrm{~g}, 0.0996 \mathrm{mmol})$ for 6 and $n$-hexanol $(2 \mathrm{~mL})$ were placed in a standard Schlenk tube in the presence of DBU (3 drops). The reaction mixture was purged by argon at room temperature and heated up to $150^{\circ} \mathrm{C}$ for $12 \mathrm{~h}$. After cooling to the room temperature, the reaction mixture was precipitated by adding methanol $(20 \mathrm{~mL})$. The precipitate was collected by centrifugation, washed several times with ethanol to dissolve any unwanted organic impurity and any unreacted metal salt and dried. Further purification of the phthalocyanine was performed by size exclusion chromatography on Biobeads gel (SX-1). The crude product was put onto the column and eluted with $\mathrm{CHCl}_{3}$, and the collected phases were concentrated on a rotary evaporator and reprecipitated with methanol. The desired pure $\mathrm{Mn}(\mathrm{III}) \mathrm{ClPc}$ (5) and $\mathrm{Mn}(\mathrm{III}) \mathrm{ClPc}(7)$ were obtained as green-brown solid.

Tetrakis[4-(4-(1H-benz[d]imidazol-2-yl)phenoxy)phthalocyaninatomanganese(III) chloride (5) Yield: $35 \%$ (0.038 g). M.p. $>250 \quad{ }^{\circ} \mathrm{C}$. $\quad$ MS (MALDI-TOF): $m / z \quad 1436.045 \quad[\mathrm{M}+1]^{+}$, $1403.453[\mathrm{M}-\mathrm{Cl}]^{+}, 1554.763[\mathrm{M}-\mathrm{Cl}+\mathrm{Matriks}]^{+}, 1578.986[\mathrm{M}-$ $\mathrm{Cl}+$ Matriks $+\mathrm{Na}+1]^{+}, \quad 1707.757 \quad[\mathrm{M}-\mathrm{Cl}+2 \text { Matriks-1 }]^{+} . \quad$ FT-IR (UATR-TWO ${ }^{\mathrm{TM}}$ ) $v_{\max } \mathrm{cm}^{-1}: 3392(\mathrm{NH}), 3186-2656(\mathrm{C}-\mathrm{H}(\mathrm{Ar})$ and intermolecular $\mathrm{H}$ bonding), 1602-1535 $(\mathrm{C}=\mathrm{N}, \mathrm{C}=\mathrm{C}), 1491-$ 1399 (C-C), 1261 (tert, C-N), 1228 (asym., Ar-O-Ar), 1165 (C-N), 1073 (sym., Ar-O-Ar), 741. UV-Vis (DMAc, $\left.1 \cdot 10^{-5} \mathrm{M}\right) \lambda_{\text {max }}(\log \varepsilon)$ nm: 266 (4.26), 311 (5.05), 640 (4.07), 718 (4.26).

Tetrakis[4-(4-(1-allyl-1H-benzo[d]imidazole-2-yl)phenoxy) phthalocyaninato manganese(III) chloride (7) Yield: $35 \%$ (0.037 g). M.p. $>250^{\circ} \mathrm{C}$. MS (MALDI-TOF): $m / z 1596.660[\mathrm{M}]^{+}, 1558.881$ $[\mathrm{M}-\mathrm{Cl}]^{+}$. FT-IR (UATR-TWO ${ }^{\mathrm{TM}}$ ) $v_{\max } \mathrm{cm}^{-1}: 3057$ (Ar., C-H), 29592851 (aliph., C-H), $1640(\mathrm{C}=\mathrm{N}), 1603-1500(\mathrm{C}=\mathrm{C}), 1469-1381$ (C-C), 1258 (tert., C-N), 1231 (asym., Ar-O-Ar), 1164 (C-N), 1078 (sym., Ar-O-Ar), 741. UV-Vis (DMAc, $\left.1 \cdot 10^{-5} \mathrm{M}\right) \lambda_{\text {max }}(\log \varepsilon) \mathrm{nm}$ : 296 (4.69), 639 (3.95), 716 (3.88).

\section{X-Ray crystal structure determination}

Single-crystal X-ray diffraction studies for the two compounds $\mathbf{1}$ and $\mathbf{3}$ were collected using a STOE IPDS II diffractometer. We also used ORTEP III $^{[15]}$ and WinGX software ${ }^{[16]}$ programs to construct figures and to prepare the manuscript for publishing. This program used for solving for the molecular structure were the direct methods procedure in SHELXS-97 and anisotropic displacement parameters were applied to non-hydrogen atoms in a full-matrix least-squares refinement based on F2 using SHELXL-97. ${ }^{[17]}$ There are some electron peaks due to disordered solvent molecules with very larger displacement parameters which were difficult to model in the unit cell of compound 3 . Therefore, the rest molecules were refined without the effect of the solvent molecules by using SQUEEZE command of PLATON.$^{[18]}$ Data collection and structure refinement parameters along with crystallographic data for two compounds are given in Table 1.

Crystallographic data were deposited in CSD under CCDC registration numbers 1549294 and 1552299 for $\mathrm{C}_{13} \mathrm{H}_{10} \mathrm{~N}_{2} \mathrm{O}$ (1) and $\mathrm{C}_{24} \mathrm{H}_{16} \mathrm{~N}_{4} \mathrm{O}$ (3) compounds, respectively. These data can be obtained free of charge from The Cambridge Crystallographic Data Center via www.ccdc.cam.ac.uk/data_request/cif.

\section{Catalytic bleaching}

Bleaching process was performed by using online spectrophotometric method to monitor the oxidation of Morin dye. ${ }^{[12,19]}$ The method used in this study enables in situ following the spec- 
Table 1. X-ray crystallographic data and refinement parameters for compounds $\mathbf{1}$ and $\mathbf{3}$.

\begin{tabular}{|c|c|c|}
\hline Compound & 1 & 3 \\
\hline \multicolumn{3}{|c|}{ Crystal data } \\
\hline Chemical formula & $\mathrm{C}_{13} \mathrm{H}_{10} \mathrm{~N}_{2} \mathrm{O}$ & $\mathrm{C}_{24} \mathrm{H}_{16} \mathrm{~N}_{4} \mathrm{O}$ \\
\hline$M r$ & 210.23 & 376.41 \\
\hline Crystal system, space group & Orthorhombic, $P$ bca & Triclinic, $P-1$ \\
\hline Temperature (K) & 296 & 296 \\
\hline$a, b, c(\AA)$ & $10.9088(9), 17.1032(11), 11.3708(7)$ & 7.8437(5), 9.9029(6), 13.7728(8) \\
\hline$\alpha, \beta, \gamma\left(^{\circ}\right)$ & $90,90,90$ & $75.503(5), 86.529(5), 87.317(5)$ \\
\hline$V\left(\AA^{3}\right)$ & $2121.5(3)$ & $1033.29(11)$ \\
\hline$Z$ & 8 & 2 \\
\hline Radiation type & Mo $K \alpha, \lambda=0.71073 \AA$ & Mo $K \alpha, \lambda=0.71073 \AA$ \\
\hline$\mu\left(\mathrm{mm}^{-1}\right)$ & 0.09 & 0.08 \\
\hline Crystal size (mm) & $0.43 \times 0.30 \times 0.14$ & $0.59 \times 0.267 \times 0.21$ \\
\hline \multicolumn{3}{|c|}{ Data collection } \\
\hline Diffractometer & STOE IPDS 2 diffractometer & STOE IPDS 2 diffractometer \\
\hline Absorption correction & Integration & Integration \\
\hline $\mathrm{T}_{\min }, \mathrm{T}_{\max }$ & $0.9633,0.9823$ & $0.9698,0.9832$ \\
\hline $\begin{array}{l}\text { No. of measured, independent and } \\
\text { observed }[I>2 \sigma(I)] \text { reflections }\end{array}$ & $12840,2081,1425$ & $11990,4048,2730$ \\
\hline $\mathrm{R}_{\text {int }}$ & 0.045 & 0.032 \\
\hline$(\sin \theta / \lambda)_{\max }\left(\AA^{-1}\right)$ & 0.617 & 0.617 \\
\hline$\theta$ range for data collection $\left(^{\circ}\right)$ & $1.8 \leq \theta \leq 27.0$ & $2 \leq \theta \leq 28.0$ \\
\hline \multicolumn{3}{|l|}{ Index ranges } \\
\hline $\mathrm{h}_{\min }, \mathrm{h}_{\max }$ & $-13,10$ & $-9,9$ \\
\hline $\mathrm{k}_{\min }, \mathrm{k}_{\max }$ & $-20,20$ & $-12,12$ \\
\hline $1_{\min }, 1_{\max }$ & $-14,14$ & $-16,16$ \\
\hline \multicolumn{3}{|c|}{ Refinement } \\
\hline$R\left[F^{2}>2 \sigma\left(F^{2}\right)\right], w R\left(F^{2}\right), S$ & $0.038,0.089,0.95$ & $0.040,0.109,1.00$ \\
\hline$H$-atom treatment & $\begin{array}{l}\text { H-atom treated by a mixture of independent and } \\
\text { constrained refinement }\end{array}$ & $H$-atom parameters constrained \\
\hline$\Delta \rho_{\max }, \Delta \rho_{\min }\left(\mathrm{e} \AA^{-3}\right)$ & $0.10,-0.17$ & $0.16,-0.13$ \\
\hline
\end{tabular}

tral changes and the determination of the amount of dye bleaching as percentage. Experiments were carried out in a reaction vessel. To the amber-colored reaction vessel placed on magnetic stirrer was added the required amount of carbonate buffer solution ( $\mathrm{pH} 10.5$ ), $80 \mathrm{mM}$ morin, $10 \mu \mathrm{M}$ catalyst and $10 \mathrm{mM}$ hydrogen peroxide for each experiment, respectively. (The catalysts were dissolved in DMF before adding to the buffer solution because DMF dissolves quite well in the water). The temperature of solutions was maintained at $25{ }^{\circ} \mathrm{C}$ with programmable water bath. The initial absorbance of morin in buffer solution was measured. Bleaching of morin was followed as the decrease in absorbance at $411 \mathrm{~nm}$. The bleaching reaction was initiated by adding $\mathrm{H}_{2} \mathrm{O}_{2}$ into the reaction mixture together with the catalyst. The continuous circulation of the mixture was provided between the reaction vessel and UV-Vis spectrophotometer by the peristaltic pump. The scanning-kinetic measurement program of the software was run for $5 \mathrm{~min}$ intervals monitoring the spectral changes throughout $45 \mathrm{~min}$. The determined bleaching percentage and absorbance changes from the measurements were graphed as the function of time. The amount of de-colorization of morin was expressed as the dye bleaching percentage and calculated by the following Eq. (1). ${ }^{[12,19]}$

$$
\% \text { Dye Bleaching }=\frac{A_{0}-A_{t}}{A_{0}} \cdot 100,
$$

where $A_{0}$ and $A_{t}$ are the absorbance of morin at time 0 and time $t$, respectively.

\section{Results and Discussion}

\section{Synthesis and spectroscopic characterization}

Scheme 1 shows the synthetic route for the target compounds 2-7.

As a first step, 2-(4-hydroxyphenyl)benzimidazole (1) was prepared by reacting of commercially available $o$-phenylenediamine with 4-hydroxybenzaldehyde in acetonitrile in the presence of $\mathrm{CoCl}_{2} \cdot 6 \mathrm{H}_{2} \mathrm{O}$ as catalyst 


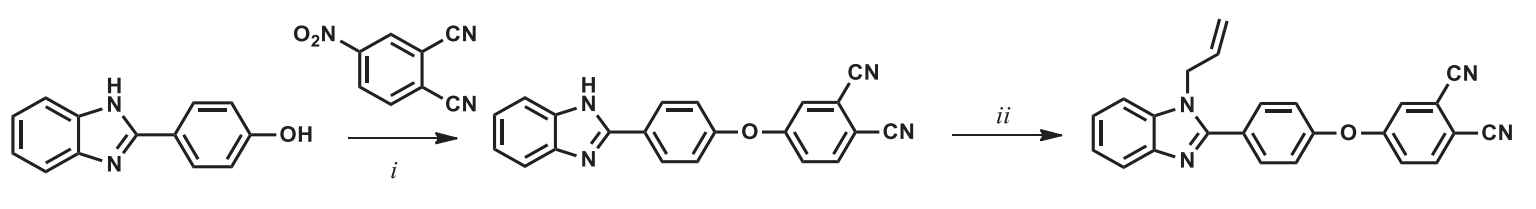

1
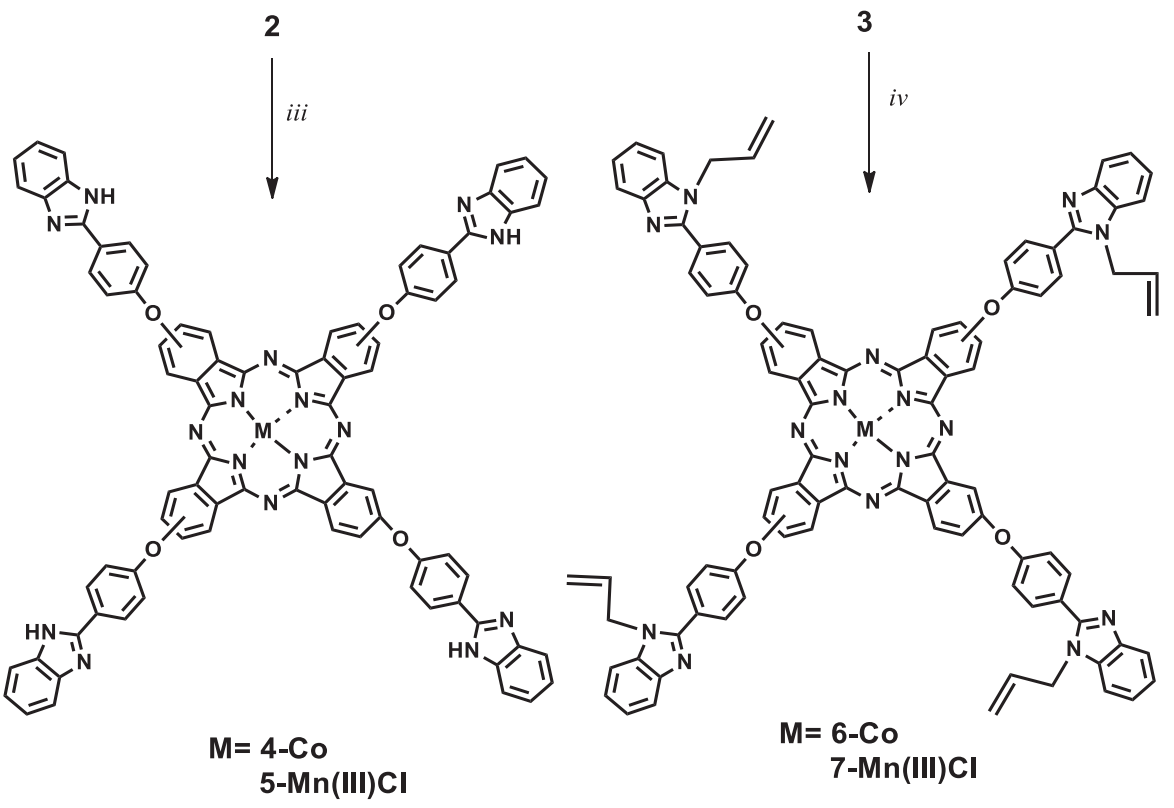

Scheme 1. Synthesis route: (i) DMF, $\mathrm{K}_{2} \mathrm{CO}_{3}$ (ii) allyl bromide, $\mathrm{DMF}, \mathrm{K}_{2} \mathrm{CO}_{3}$ (iii) and (iv) $n$-pentanol, $\mathrm{DBU}, \mathrm{Co}(\mathrm{OAc})$, for 4 and $\mathbf{6}$, $n$-hexanol, anhydrous $\mathrm{MnCl}_{2}, \mathrm{DBU}$ for $\mathbf{5}$ and 7.

using the literature procedure. ${ }^{[14]}$ The one of the main precursors, molecule $\mathbf{2}$, was obtained by aromatic substitution reaction of $\mathbf{1}$ and 4-nitrophthalonitrile using $\mathrm{K}_{2} \mathrm{CO}_{3}$ as catalyst in DMF with stirring at $60{ }^{\circ} \mathrm{C}$ for $24 \mathrm{~h}$. The pure product was achieved with a good yield (96\%). The other starting material, compound $\mathbf{3}$, was obtained by the reaction of 2 and allyl bromide using $\mathrm{K}_{2} \mathrm{CO}_{3}$ as base in DMF at $70^{\circ} \mathrm{C}$ for $24 \mathrm{~h}$. Further purification of $\mathbf{2}$ was performed by column chromatography (silica gel, eluent: $\mathrm{CHCl}_{3}-\mathrm{MeOH} 10: 1$ ) resulting in $95 \%$ yield. Suitable crystals of the molecules (1 and 3) for X-ray analysis were obtained upon crystallization from $\mathrm{CHCl}_{3}$ solution.

The required new phthalocyanines 4-7 were prepared from the cyclotetramerization reaction of 4-(4-(1H-benz $[d]$ imidazol-2-yl)phenoxy) group substituted phthalonitrile (2) for 4 and $\mathbf{5}$ and 4-(4-(1-allyl-1H-benz[ $d]$ imidazol-2-yl)phenoxy) group substituted phthalonitrile (3) for 6 and 7 in high boiling solvents such as $n$-pentanol or $n$-hexanol with anhydrous metal salts $\left(\mathrm{Co}(\mathrm{OAc})_{2}\right.$ and $\left.\mathrm{MnCl}_{2}\right)$ and $\mathrm{DBU}$ as a strong base. The purification of the prepared phthalocyanines 4-7 was performed by size exclusion chromatography on Biobeads gel (SX-1) by eluting $\mathrm{CHCl}_{3}$ resulting in $42 \%$, $35 \%, 52 \%$ and $35 \%$ yield, respectively.

Characterization of the products was carried out a combination of methods including determination of melting point, FT-IR, ${ }^{1} \mathrm{H}$ NMR, ${ }^{13} \mathrm{C}$ NMR, UV-Vis spectroscopy and mass spectrometry. All the spectral data are in accordance with the proposed structures.

When compared the FT-IR spectra of $\mathbf{1}$ and $\mathbf{2}$, the disappearance of -OH vibration at $3434 \mathrm{~cm}^{-1}$ and the appearance of new absorption bands at $2232 \mathrm{~cm}^{-1}$ and $1246 \mathrm{~cm}^{-1}$ belonging to the $-\mathrm{C} \equiv \mathrm{N}$ and Ar-O-R, respectively, clearly indicate the formation of $\mathbf{2}$. The formation of $\mathbf{3}$ can be recognized from the disappearance of $-\mathrm{NH}$ vibration at $3576 \mathrm{~cm}^{-1}$ and the appearance of aliphatic $-\mathrm{CH}$ vibrations at $2985-2855 \mathrm{~cm}^{-1}$. In addition, the $-\mathrm{C} \equiv \mathrm{N}$ vibration at 2231 $\mathrm{cm}^{-1}$ and the $-\mathrm{C}=\mathrm{N}$ vibration at $1644 \mathrm{~cm}^{-1}$ are observed for compound 3. Formation of 4-(4-(1H-benz $[d]$ imidazol-2-yl) phenoxy) group and 4-(4-(1-allyl- $1 H$-benz $[d]$ imidazol2-yl)phenoxy) substituted Pc complexes 4-7 starting from the corresponding phthalonitrile ( 2 and $\mathbf{3}$ ) derivatives were proved by the disappearance of the $-\mathrm{C} \equiv \mathrm{N}$ stretching vibration bands at $2232 \mathrm{~cm}^{-1}$ for compounds $\mathbf{4}$ and $\mathbf{5}$ and $2231 \mathrm{~cm}^{-1}$ for compounds 6 and 7, as a proof of the cyclotetramerization reaction of dinitrile.

The ${ }^{1} \mathrm{H}$ NMR data gave satisfactory information about the proposed structures of the target compounds. When compared the ${ }^{1} \mathrm{H}$ NMR spectra of compound $\mathbf{1}$ and $\mathbf{2}$, the disappearances of $\mathrm{OH}$ proton signal of 2-(4-hydroxyphenyl)benzimidazole (1) and the appearance of new peaks in aromatic region at $8.26-7.20 \mathrm{ppm}$ and the $-\mathrm{NH}$ peak at $5.74 \mathrm{ppm}$ were the evidence of the formation of phthalonitrile derivative 2 (in supporting information). In the ${ }^{1} \mathrm{H}$ NMR spectra of $\mathbf{3}$, the disappearances of -NH proton signal originating from starting phthalonitrile and the existence of protons of allyl group at $6.16-4.88 \mathrm{ppm}$ as distinct from compound $\mathbf{2}$ clearly indicate the formation of $\mathbf{3}$ (in Supporting information).

In the ${ }^{13} \mathrm{C}$ NMR spectrum of $\mathbf{2}$ the presence of the signals at $117.47 \mathrm{ppm}$ and $116.60 \mathrm{ppm}$ attributed to the nitrile carbon atoms are the obvious differences from 1 (in Supporting information). For the ${ }^{13} \mathrm{C}$ NMR spectrum of 3 , the characteristic signals were observed at the range of $161.31-109.68 \mathrm{ppm}$ and $47.44 \mathrm{ppm}$ related to aromatic- 
the allyl group $(\mathrm{C}=\mathrm{C})$ carbon peaks and allyl group $\left(\mathrm{CH}_{2}\right)$ carbon peak, respectively (in Supporting information).

The ${ }^{1} \mathrm{H}$ NMR and ${ }^{13} \mathrm{C}$ NMR spectra of phthalocyanines 4-7 could not be taken due to the paramagnetic cobalt(II) and manganese(III) center.

The mass spectra of 2-7 were obtained by the MALDITOF mass spectrometer confirming the proposed structures. In the mass spectra of 2-7, the presence of molecular ion peaks observed at high intensity and easily identified at $\mathrm{m} / \mathrm{z}$ : $336.081[\mathrm{M}]^{+}$for 2, $\mathrm{m} / \mathrm{z} 375.853[\mathrm{M}+1]^{+}$for 3, $\mathrm{m} / \mathrm{z}: 1404.549$ $[\mathrm{M}]^{+}$for 4, $m / z 1436.045[\mathrm{M}+1]^{+}$for $\mathbf{5}, \mathrm{m} / z 1564.099[\mathrm{M}]^{+}$for 6 and $\mathrm{m} / z$ 1596.660 [M] $]^{+}$for 7 clearly indicates the formation of desired products, respectively, as seen in supporting information.

The ground-state electronic spectroscopy is one of the most useful methods for the determination of structural properties of phthalocyanines. Generally, phthalocyanine compounds display two intense absorption bands in the electronic spectra. One of them is observed in the visible region of spectrum at around 600-700 nm ( $Q$-band) and the other one is in the UV region at around $300-350 \mathrm{~nm}$ ( $B$-band), and both of them are correlated to $\pi-\pi^{*}$ transitions. ${ }^{[20]}$

The electronic spectra of the prepared phthalocyanines were recorded in three different solvents (DMAc,
DMF and DMSO) and the synthesized phthalonitrile derivatives were recorded in DMSO, comparatively, as shown in Figure 1.

The UV-Vis absorption spectra of phthalonitrile derivatives ( 2 and $\mathbf{3}$ ) showed the maximum absorptions at $311 \mathrm{~nm}$ for $\mathbf{2}$ and at $295 \mathrm{~nm}$ for $\mathbf{3}$ which can be assigned to $\pi \rightarrow \pi^{*}$ transitions (Figure 1). ${ }^{[21]}$

Cobalt phthalocyanines (4 and 6) showed intense $Q$-absorption band at $666 \mathrm{~nm}$ for 4 and $667 \mathrm{~nm}$ for 6 with no splitting on them which assigned that it was metallophthalocyanine with the $D_{4 h}$ symmetry as expected (Figure 1a, 1c). ${ }^{[22]}$

In manganese phthalocyanines (5 and 7) the spectrum may consist of two or three bands corresponding to different species in solution. The formation of broad band around $620 \mathrm{~nm}$ and decrease in $Q$-band absorption indicate the formation of non-covalent $\mathrm{MnPc}$ aggregates originating $\mu$-oxo dimers in coordinating solvents (Figure 1b, 1d). ${ }^{[23]}$

When MnPcs 5 and 7 are dissolved in DMF and DMSO, we observe the considerable amount of manganese $\mu$-oxo dimer form at about $620 \mathrm{~nm}$; if they are dissolved in DMAc the dimer form reveals at about $640 \mathrm{~nm}$ and $Q$-absorption bands at $718 \mathrm{~nm}$ for $\mathbf{5}$ and $716 \mathrm{~nm}$ for $\mathbf{7}$ which confirms that the manganese phthalocyanines show a highly red-shifted $Q$-band ${ }^{[24]}$ (Figure 1b, 1d).
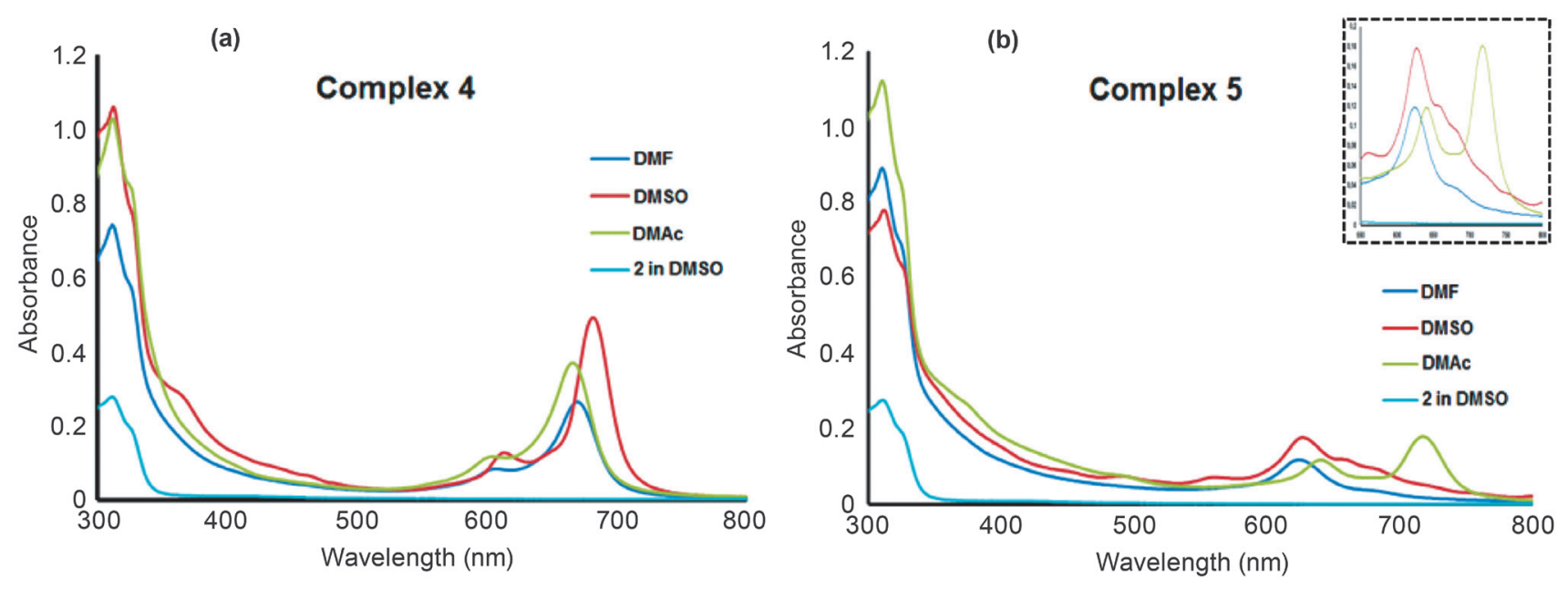

(c)

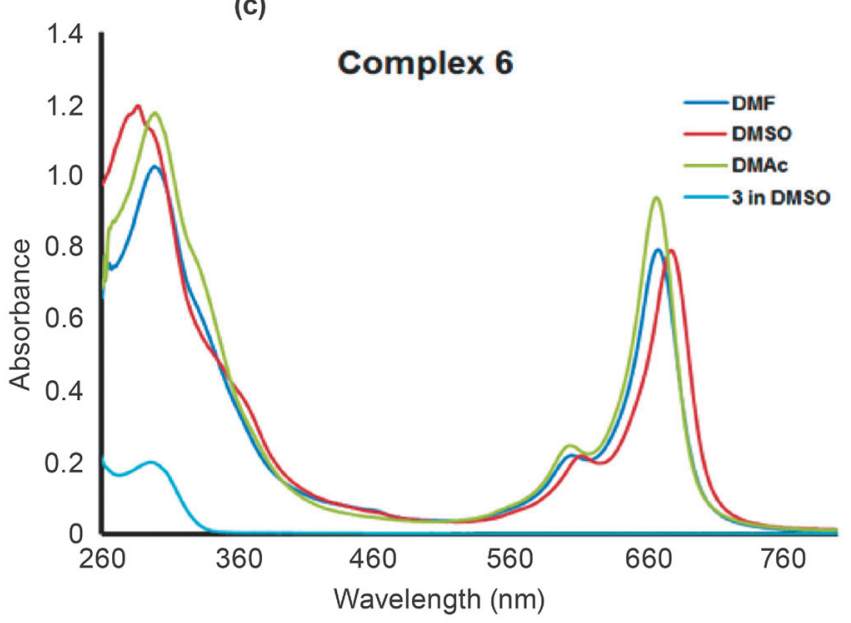

(d)

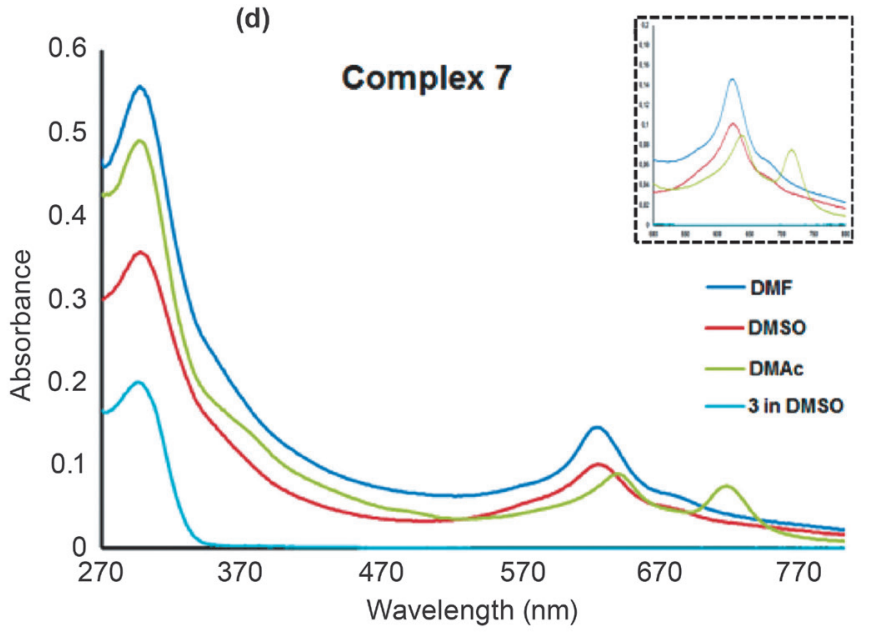

Figure 1. Absorption spectra of compounds 4-7 in DMAc, DMF and DMSO (concentration $1 \cdot 10^{-5} \mathrm{~mol} \cdot \mathrm{L}^{-1}$ ). 


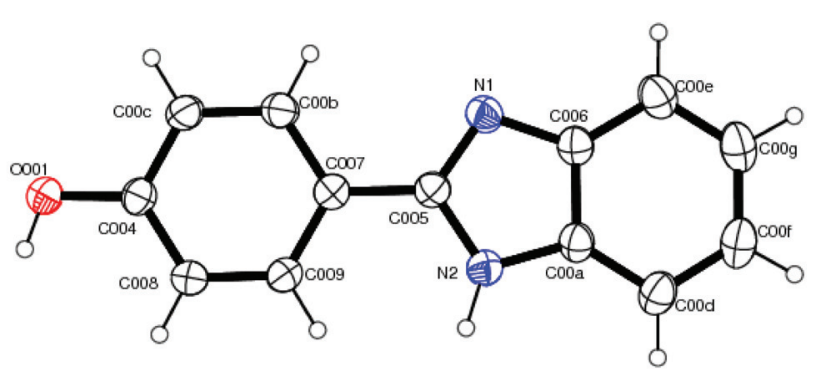

Figure 2. The ORTEP view of the compound 1 shows atomic labeling scheme and $30 \%$ probability level displacement ellipsoids.

\section{Description of the crystal structures}

The crystal structure analysis of $\mathbf{1}$ and $\mathbf{3}$ showed that the compounds are 2-(4-hydroxyphenyl)benzimidazole and 4-(4-(1-allyl-1H-benz $[d]$ imidazole-2-yl)phenoxy) phthalonitrile, respectively. The ORTEP plots of the compounds $\mathbf{1}$ and $\mathbf{3}$ are shown in Figures 2 and 3, respectively. Selected bond lengths and bond angles obtained from the crystallographic analysis are summarized in Table 2, while $H$-bond geometries are listed in Table 3 . Compound $\mathbf{1}$ contains two ring systems, the dihedral angle between benzimidazole and hydroxyphenyl groups are formed by these planes is $0.9(1)^{\circ}$. The $\mathrm{C}-\mathrm{N}$ bond lengths in the imidazole ring are in the range 1.323(2)-1.386(2) $\AA$, indicating partial double bond character. Crystal structure of 1 the title compound has a $\mathrm{C}-\mathrm{H} \cdots \mathrm{N}$ intramolecular hydrogen bond, a strong $\mathrm{O}-\mathrm{H} \cdots \mathrm{N}$ and $\mathrm{N}-\mathrm{H} \cdots \mathrm{O}$ intermolecular hydrogen bond.

The molecular structure 3 has phenoxy ring, phthalonitrile, benz $[d]$ imidazole ring and 1-allyl-1 $H$ group attached

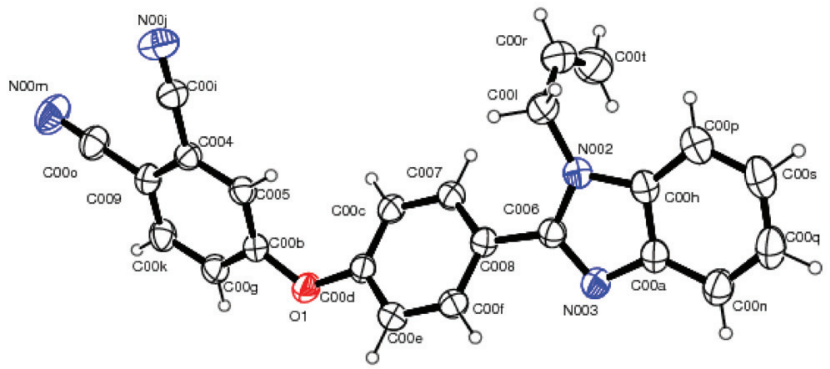

Figure 3. The ORTEP view of the compound $\mathbf{3}$ shows atomic labelling scheme and $30 \%$ probability level displacement ellipsoids.

to benz $[d]$ imidazole ring. The bond lengths of cyano, $\mathrm{C} \equiv \mathrm{N}$ in the structure are in the range of 1.323-1.396 $\AA$ and comparable with the related structure. ${ }^{[25]}$ Compound 3 shows that there is no usual hydrogen bonding in this structure, but there are weak intra- and intermolecular $\mathrm{C}-\mathrm{H} \cdots \mathrm{N}$ and $\mathrm{C}-\mathrm{H} \cdots \mathrm{O}$ inter-molecular interactions which may be active in the stabilization of their unit cell. Crystal packing diagrams of both compounds are given in Figures 4, 5 and details as shown in Table 3 .

\section{Bleach Performance}

Bleaching agents are active component in lots of cleaning product, including standard domestic powder detergents for laundry. The main functions of a bleach system are to provide whiter clothing and to remove quite different kind of soils and stains. Bleach systems work through the oxidation reactions of hydrogen peroxide as powerful oxidizing agent with chromophore group resulting colorful substrates

Table 2. Selected bond lengths $(\AA)$ and angles $\left({ }^{\circ}\right)$ for the $\mathbf{1}$ and $\mathbf{3}$ compounds.

\begin{tabular}{cccc}
\hline & 1 & & 3 \\
\hline & & Bond lengths $(\AA)$ & $1.363(17)$ \\
\hline O001-C004 & $1.361(17)$ & $\mathrm{O} 1-\mathrm{C} 00 \mathrm{~b}$ & $1.397(17)$ \\
$\mathrm{N} 1-\mathrm{C} 005$ & $1.323(18)$ & $\mathrm{O} 1-\mathrm{C} 00 \mathrm{~d}$ & $1.370(19)$ \\
$\mathrm{N} 1-\mathrm{C} 006$ & $1.396(18)$ & $\mathrm{N} 002-\mathrm{C} 006$ & $1.385(18)$ \\
$\mathrm{N} 2-\mathrm{C} 005$ & $1.363(18)$ & $\mathrm{N} 002-\mathrm{C} 00 \mathrm{~h}$ & $1.459(2)$ \\
$\mathrm{N} 2-\mathrm{C} 00 \mathrm{a}$ & $1.383(19)$ & $\mathrm{N} 002-\mathrm{C} 001$ & $1.320(18)$ \\
& & $\mathrm{N} 003-\mathrm{C} 006$ & $1.386(18)$ \\
& & $\mathrm{N} 003-\mathrm{C} 00 \mathrm{a}$ & $1.136(2)$ \\
$\mathrm{C}$ & & $\mathrm{N} 00 \mathrm{~m}-\mathrm{C} 00 \mathrm{o}$ & $1.139(2)$ \\
$\mathrm{C} 005-\mathrm{N} 1-\mathrm{C} 006$ & $\mathrm{C} 00 \mathrm{i}-\mathrm{N} 00 \mathrm{j}$ & $122.97(11)$ \\
$\mathrm{O} 001-\mathrm{N} 2-\mathrm{C} 00 \mathrm{a}-\mathrm{C} 00 \mathrm{c}$ & $105.73(12)$ & $\mathrm{C} 00 \mathrm{~b}-\mathrm{O} 1-\mathrm{C} 00 \mathrm{~d}$ & $177.86(18)$ \\
$\mathrm{O} 001-\mathrm{C} 004-\mathrm{C} 008$ & $108.10(13)$ & $\mathrm{N} 00 \mathrm{C}-\mathrm{C} 00 \mathrm{i}-\mathrm{C} 004$ & $178.9(2)$ \\
$\mathrm{N} 1-\mathrm{C} 005-\mathrm{N} 2$ & $118.43(13)$ & $\mathrm{N} 00 \mathrm{M}-\mathrm{C} 00 \mathrm{O}-\mathrm{C} 009$ & $110.24(13)$ \\
$\mathrm{N} 2-\mathrm{C} 005-\mathrm{C} 007$ & $122.40(13)$ & $\mathrm{N} 003-\mathrm{C} 00 \mathrm{a}-\mathrm{C} 00 \mathrm{~h}$ & $125.08(13)$
\end{tabular}


Table 3. Hydrogen-bond geometries $\left(\AA,^{\circ}\right)$ for the $\mathbf{1}$ and $\mathbf{3}$ compounds.

\begin{tabular}{cccccc}
\hline Compound 1 & $D-\mathrm{H} \cdots A$ & $D-\mathrm{H}$ & $\mathrm{H} \cdots A$ & $D \cdots A$ & $D-\mathrm{H}^{\cdots} A\left(^{\circ}\right)$ \\
\hline & $\mathrm{C} 009-\mathrm{H} 009 \cdots \mathrm{N} 2$ & 0.93 & 2.59 & 2.906 & 101 \\
& $\mathrm{O} 001-\mathrm{H} 001 \cdots \mathrm{N} 1^{\mathrm{i}}$ & 0.82 & 1.837 & 2.653 & 173 \\
& $\mathrm{~N} 2-\mathrm{H} 2 \mathrm{a}^{\circ} \mathrm{O} 001^{\mathrm{ii}}$ & 0.908 & 2.073 & 2.919 & 154 \\
\hline Symmetry-Code & & $\mathrm{i}: \mathrm{x},-\mathrm{y}+3 / 2, \mathrm{z}+1 / 2 ; \mathrm{ii}: \mathrm{x}+1 / 2,-\mathrm{y}+3 / 2,-\mathrm{z}+1$ & & \\
\hline Compound 3 & $D-\mathrm{H} \cdots A$ & $D-\mathrm{H}$ & $\mathrm{H} \cdots A$ & $D \cdots A$ & $D-\mathrm{H} \cdots A\left(^{\circ}\right)$ \\
& $\mathrm{C} 00 \mathrm{t}-\mathrm{H} 00 \mathrm{~d} \cdots \mathrm{N} 002$ & 0.93 & 2.55 & $2.868(3)$ & 101 \\
& $\mathrm{C} 005-\mathrm{H} 005 \cdots \mathrm{N} 00 \mathrm{j}^{\mathrm{i}}$ & 0.93 & 2.91 & $3.345(2)$ & 139 \\
& $\mathrm{C} 00 \mathrm{t}-\mathrm{H} 00 \mathrm{~d} \cdots \mathrm{O}^{\mathrm{ii}}$ & 0.93 & 2.76 & $3.357(18)$ & 123 \\
\hline
\end{tabular}

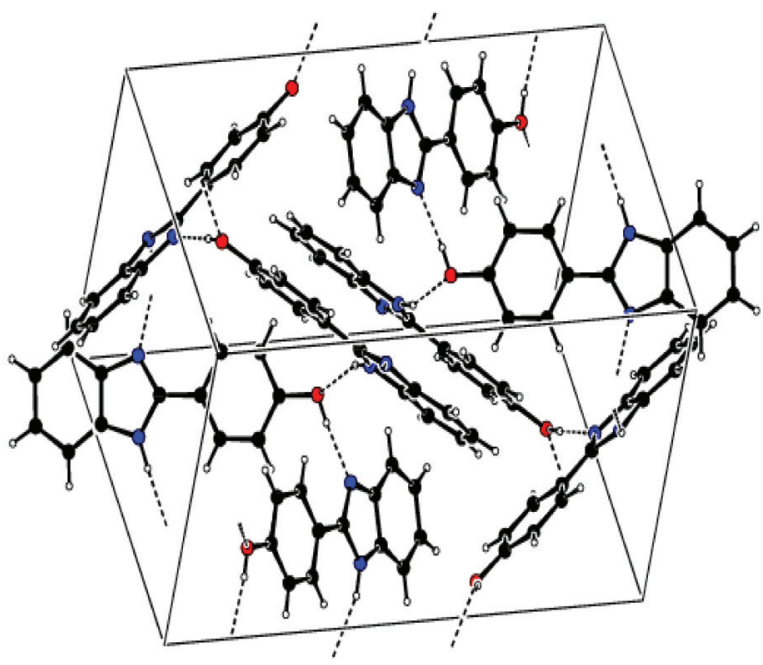

Figure 4. A partial view of the packing of compound $\mathbf{1}$, showing strong $\mathrm{O}-\mathrm{H} \cdots \mathrm{N}$ hydrogen bonding interactions as dashed lines.

via degrading into colorless or water-soluble products. ${ }^{[26]}$ A continuing trend in washing conditions is the lowering of wash temperatures to gain energy saving and to avoid the deformation of fabrics.

For this purpose, we have developed new kind of bleach catalysts. To evaluate the ability of the synthesized phthalocynanines (4-7) for the activation of $\mathrm{H}_{2} \mathrm{O}_{2}$ and the catalytic oxidation performance in aqueous solutions, morin dye was chosen as model marker for wine stain. ${ }^{[27]}$

The experiments were carried out at constant temperature $\left(25^{\circ} \mathrm{C}\right)$ with $10 \mu \mathrm{M}$ catalyst, $80 \mu \mathrm{M}$ morin and $10 \mathrm{mM}$ $\mathrm{H}_{2} \mathrm{O}_{2}$ in $10 \mathrm{mM}$ buffer solution $(100 \mathrm{~mL})$ by using deionized water at $\mathrm{pH} 10.5$ to provide basic detergent conditions. While

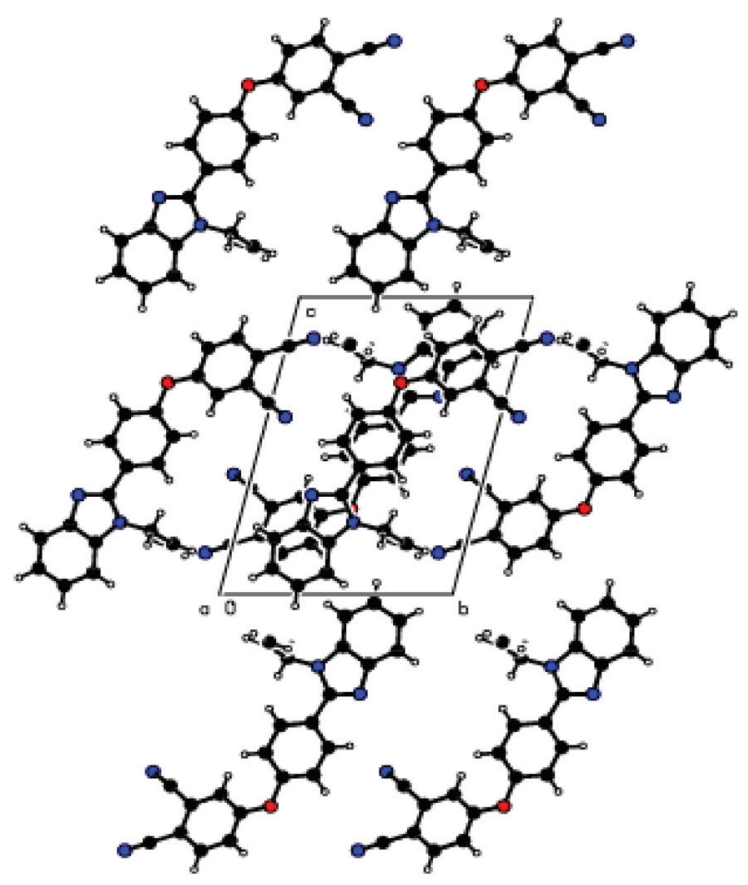

Figure 5. Crystal-packing diagram of compound 3.

catalysts 6, 7 soluble in common organic solvents, catalysts 4, 5 are soluble in DMF and DMSO. Therefore, the catalysts were dissolved in DMF before adding to the buffer solution because DMF dissolves quite well in the water.

The applied bleach process condition is presented in Figure 6. The proposed colorless water-soluble degradation products for morin dye are 2,4-dihydroxybenzoic acid and 2,4,6-trihydroxybenzoic acid as seen in our recent study. ${ }^{[19]}$<smiles>O=c1c(O)c(-c2ccc(O)cc2O)oc2cc(O)cc(O)c12</smiles>

$80 \mu \mathrm{M}$ Morin $25^{\circ} \mathrm{C}, \mathrm{pH}: 10.5$

$\underset{10 \mathrm{mM} \text { Buffer Solution }}{10 \mathrm{mM} \mathrm{H} \mathrm{O}_{2}}$
$10 \mu \mathrm{M}$ Catalyst

$10 \mu \mathrm{M}$ Catalyst

Figure 6. Conditions for bleaching process of morin. 
The mechanism of the bleaching is based on the activation of hydrogen peroxide to produce perhydroxyl anion $\left(\mathrm{HO}_{2}^{-}\right)$(Eq. 2). Catalytic reaction of phthalocyanines containing redox active metals was carried out by the coordination of the active oxidative intermediate $\left(\mathrm{OOH}^{-}\right)$to the central metal ion to form PcM-OOH species (Eq. 3). ${ }^{[28,29]}$ These intermediates are the key step in the catalytic cycle and expected to be highly reactive than hydrogen peroxide alone.

$$
\begin{aligned}
& \mathrm{H}_{2} \mathrm{O}_{2} \rightleftarrows \mathrm{H}^{+}+\mathrm{OOH}^{-} \stackrel{\mathrm{OH}}{\longrightarrow} \mathrm{H}_{2} \mathrm{O}+\mathrm{OOH}^{-} \\
& \mathrm{PcM}+\mathrm{OOH}^{-} \longrightarrow[\mathrm{PcM}-\mathrm{OOH}]
\end{aligned}
$$

The bleaching activity of the prepared phthalocyanine based hydrogen peroxide-activating catalysts (4-7) in presence of oxidant $\left(\mathrm{H}_{2} \mathrm{O}_{2}\right), \mathrm{H}_{2} \mathrm{O}_{2}$ alone without using catalyst and oxidant $\left(\mathrm{H}_{2} \mathrm{O}_{2}\right)$ with commercial TAED used in detergent formulations as the bleach activator were shown by monitoring the spectral transformations of the morin, as seen in Figure 7.

The absorbance of the morin dye in buffer solution decreased by the addition of hydrogen peroxide/catalyst combination with the increase of reaction time. These changes in absorption monitoring in UV-Vis spectroscopy indicate the oxidative degradation of morin and reflect the catalytic activity of the complexes. During the course
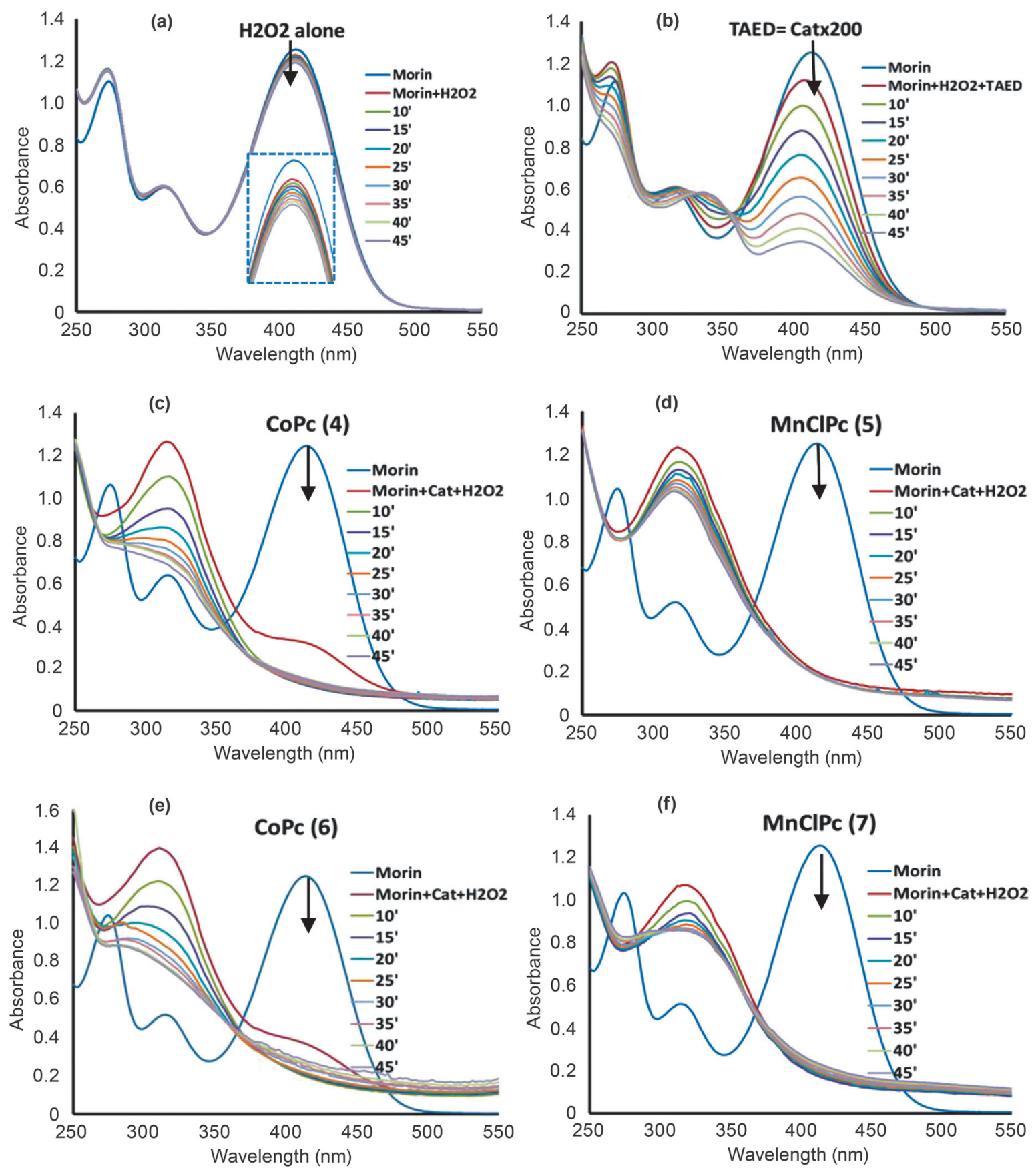

Figure 7. UV-Visible spectral changes of morin in bleaching experiments at $25^{\circ} \mathrm{C}$ : (a) with $\mathrm{H}_{2} \mathrm{O}_{2}$ without any catalyst; (b) commercial TAED, 200-fold of prepared catalysts; (c) CoPc 4; (d) MnClPc 5; (e) CoPc 6; (f) MnClPc 7. 
of the reaction, also, a new absorbance peak at around $300 \mathrm{~nm}$ appears which is increasing with time. This new band visibly illustrates that morin is oxidizing, and a single intermediate product is formed for the observed time period. This is in agreement with the report in the literature. ${ }^{[30]}$

The bleach performances of oxidant alone and TAED+oxidant, oxidant+catalyst combinations were determined in terms of de-coloration percentage and bleaching speed of morin.

The degradation of morin with $\mathrm{H}_{2} \mathrm{O}_{2}$ in the carbonate buffer does not proceed in the experiments without any catalyst or activator. Clearly the Figure 7a shows that only a small decrease of the morin concentration occurred in the absence of the catalyst with $\mathrm{H}_{2} \mathrm{O}_{2}$ alone while a systematic decay of absorbance was observed with TAED $+\mathrm{H}_{2} \mathrm{O}_{2}$ combination after 45 min (Figure 7b).

The catalytic hydrogen peroxide oxidation of the morin with the prepared phthalocyanine complexes (4-7) as seen in Figure $7 \mathrm{c}-7 \mathrm{f}$ shows that addition of the phthalocyanine catalysts (4-7) to the dye solution has significantly increased the efficacy of the hydrogen peroxide oxidation of the morin and enhanced the reaction kinetic.

When the UV-Vis spectral changes of morin at bleach experiments were evaluated, it was determined that the $\mathrm{CoPc} \mathbf{4}$ had the most efficient oxidative catalytic activity as a function of total bleaching percentage with $90.41 \%$ (Figure 7c). The percentages of de-colorations for the other catalysts were observed as $84.61 \%$ for 5, $86.83 \%$ for $\mathbf{6}$ and $85.84 \%$ for 7 . From the obtained results it was observed that the order of the catalyst activity was $\mathrm{CoPc}(4)>\mathrm{CoPc}$ (6) $>\mathrm{MnClPc}(7)>\operatorname{MnClPc}(5)$ as the function of the total bleaching percentage. It was seen that CoPcs (4 and 6) more effective than MnClPcs (5 and 7) even if the bleach performance difference among them is almost $5 \%$ as decoloration percentage (Figure 7c-7f). It could be concluded that under alkaline $\mathrm{pH}$ conditions, the relative catalytic activity of the MPc complexes [i.e. $\mathrm{Co}(\mathrm{II})>\mathrm{Mn}$ (II)] follows a trend that reflects the ability of the transition metal to form coordination complexes with the reactants. ${ }^{[31]}$

The performances of the prepared catalysts were also characterized as the bleaching speed. The absorption peaks at $411 \mathrm{~nm}$ in the visible region exhibited a rapid diminish for all catalysts. Degradation of morin was completed just after adding hydrogen peroxide/catalyst after 5 min for compounds 5 and 7 (Figure 7d-7f), after 10 min for compounds 4 and 6 (Figure 7c-7e).

The obtained bleaching results of the prepared complexes 4-7 were compared with commercial TAED. It was observed that the catalysts had more bleaching efficiency, even though 200 fold TAED was used (Figure 7b) and the performance of peroxide bleaching is insufficient without using catalyst at ambient temperature alone (Figure 7a).

Selected results were plotted as percentage of bleaching and change in absorbance versus time (Figure 8). The results related with the percentages of de-colorations and the completion time of the bleaching are tabulated in detail (Table 4).

In recent applications, the benefit-damage balance has been taken into consideration. In the first 20 minutes of the experiment, prepared bleach catalysts reached the almost maximum bleaching effect (Figure 9).

\section{Conclusion}

Presented study describes new cobalt and manganese phthalocyanine derivatives as bleach catalysts for laundry applications. We have investigated the catalytic activity of the prepared complexes activating hydrogen peroxide for the oxidative degradation of morin in a carbonate containing aqueous solution under mild reaction conditions. We used on-line spectrophotometric system for in situ monitoring of spectral changes during the examination of degradation of morin dye. The results showed that the prepared phthalocyanine catalysts have very high bleach activity. It was found that adding a very small amount of a suitable catalyst resulted in significantly improved bleaching effect and speed. The maximum effect was obtained using bleach catalysts in the first 20 minutes of the experiment. These results are important in terms of washing times. With this feature, bleach catalysts provide energy saving as well as cost-effective. When compared to the commercial TAED or $\mathrm{H}_{2} \mathrm{O}_{2}$ alone, we obtained more effective bleaching in a short time by applying the prepared complexes as bleach catalysts. (a)

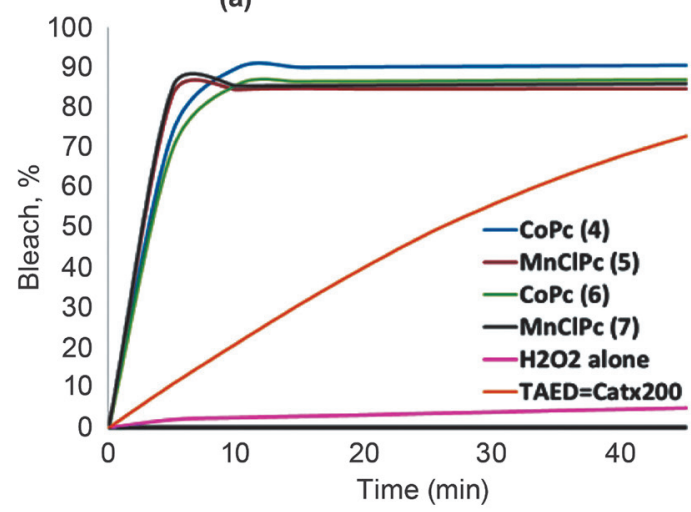

(b)

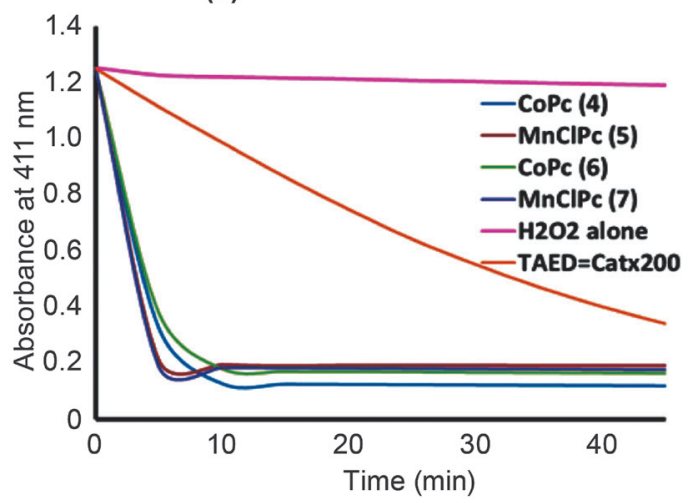

Figure 8. Time dependence of dye oxidation under homogeneous conditions at $25^{\circ} \mathrm{C}$. a) $\%$ decoloration, b) the changes of absorbance at $411 \mathrm{~nm}$ 
Table 4. The results of decoloration of morin under homogeneous conditions.

\begin{tabular}{cccc}
\hline Catalyst & $\begin{array}{c}\text { The completion time } \\
\text { of the bleaching }(\mathrm{min})\end{array}$ & $\begin{array}{c}\text { Bleaching, } \% \\
\text { (in the first 20 min) }\end{array}$ & $\begin{array}{c}\text { Bleaching, \% } \\
(45 \mathrm{~min})\end{array}$ \\
\hline $\mathbf{4}$ & 10 & 90.01 & 90.41 \\
$\mathbf{5}$ & 5 & 84.53 & 84.61 \\
$\mathbf{6}$ & 10 & 86.42 & 86.83 \\
$\mathbf{7}$ & 5 & 85.44 & 85.84 \\
$\mathrm{H}_{2} \mathrm{O}_{2}$ alone & - & 3.19 & 4.94 \\
TAED=Catx200 & - & 40.21 & 72.82 \\
\hline
\end{tabular}

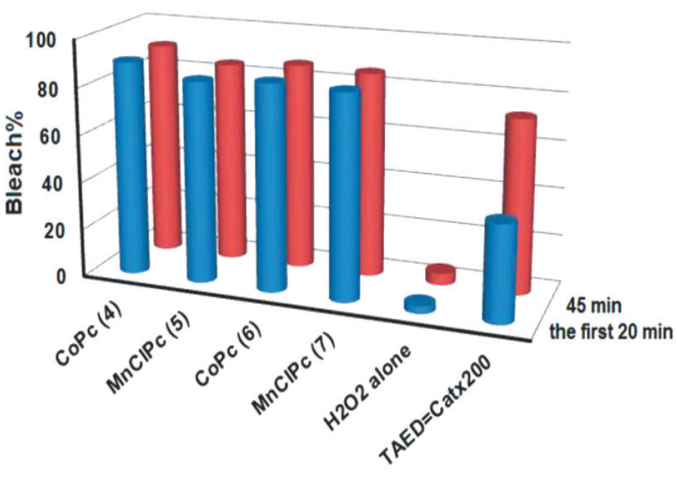

Figure 9. Bleach performance comparison of the prepared complexes with TAED and $\mathrm{H}_{2} \mathrm{O}_{2}$ without using catalyst in the first $20 \mathrm{~min}$ and $45 \mathrm{~min}$.

Acknowledgement. This work was supported by Ministry of Science, Industry and Technology of Turkey (SANTEZ project no. 0182.STZ.2013-1) and Research Fund of Sakarya University (project no. 2014-02-04 007).

\section{References}

1. McKeown N.B. Phthalocyanine Materials Synthesis, Structure and Function. Cambridge: Cambridge University Press, 1998.

2. Leznoff C.C., Lever A.B.P. Phthalocyanines: Properties and Applications. New York: VCH, 1989-1996.

3. Skobelev I.Y., Kudrik E.V., Zalomaeva O.V., Albrieux F., Afanasiev P., Kholdeev O.A., Sorokin A.B. Chem. Commun. 2013, 49, 5577-5579.

4. Agboola B., Ozoemena K.I., Nyokong T. J. Mol. Catal. A: Chem. 2005, 227, 209-216.

5. Saka E.T., Çağlar Y. Catal. Lett. 2017, 147, 1471-1477.

6. Sorokin A.B. Chem. Rev. 2013, 113, 8152-8191.

7. Turk H., Cimen Y. J. Mol. Catal. A: Chem. 2005, 234, 19-24.

8. Matemadombo F., Durmus M., Escriou V., Griveau S., Scherman D., Bedioui F., Nyokong T. Current Analytical Chemistry 2009, 5, 330-338.
9. Nas A., Dilber G., Durmus M., Kantekin H. Spectrochim. Acta, Part A: Molecular and Biomolecular Spectroscopy 2015, 135, 55-62.

10. Nwaji N., Bankole O.M., Britton J., Nyokong T. J. Porphyrins Phthalocyanines 2017, 21, 1-10.

11. (a) Sehwenkmis T., Berkeasel A. Tetrahedron Lett. 1993, 34, 4785-4788; (b) Bozell J.J., Hames B.R. J. Org. Chem. 1995, 60, 2398-2404.

12. Tunç S., Duman O., Gürkan T. Ind. Eng. Chem. Res. 2013, 52, 1414-1425.

13. Perrin D.D., Armarego W.L.F., Perrin D.R. Purification of Laboratory Chemicals. New York: Pergamon Press, 2013.

14. Khan A.T., Parvin T., Choudhury L.H. Synth. Commun. 2009, 39, 2339-2346.

15. Farrugia L.J. J. Appl. Crystallogr. 1997, 30, 565.

16. Farrugia L.J. J. Appl. Crystallogr. 1999, 32, 837-838.

17. Sheldrick G.M. SHELXS97 and SHELXL97. Germany: University of Gottingen, 1997.

18. Spek A.L. Acta Crystallogr., Sect D: Biol. Crystallogr. 2009, D65, 148-155.

19. Sen P., Simsek D.K., Yildiz S.Z. Appl. Organomet. Chem. 2015, 29, 509-516.

20. Kobayashi N. Coord. Chem. Rev. 2002, 227, 129-152.

21. Liu S., Zuo J., Li Y., You X. J. Mol. Struct. 2004, 705, 153157.

22. Nyokong T. Coord. Chem. Rev. 2007, 251, 1707-1722.

23. Canham G.W.R., Lever A.B.P. Inorg. Nucl. Chem. Lett. 1973, 9, 13-17.

24. Stillman M.J. In: The Porphyrin Handbook (Leznoff C.C., Lever A.B.P., Eds.) Vol. 3. New York: VCH, 1993.

25. Saral H., Ozdamar O., Uçar I. J. Mol. Struct. 2017, 1130, 4654.

26. Bianchetti G.O., Devlin C.L., Seddon K.R. RSC Adv. 2015, 5, 65365-65384.

27. Wieprecht T., Hazenkamp M., Rohwer H., Schlingloff G., Xia J.C.R. Chimie 2007, 10, 326-40.

28. Agboola B., Ozoemena K.I., Nyokong T. J. Mol. Catal. A: Chem. 2005, 227, 209-216.

29. Sharma R.K., Gulati S. J. Mol. Catal. A: Chem. 2012, 363364, 291-303.

30. Nemanashi M., Meijboom R. Langmuir 2015, 31, 9041-9053.

31. Hoffmann M.R., Hong A.P.K. The Science of the Total Environment. Amsterdam: Elsevier Science Publishers, 1987. 